\title{
5'-Deiodinase Activity and Circulating Thyronines in Lactating Cows
}

\author{
C. Pezzi, ${ }^{\star}$ P. A. Accorsi, ${ }^{\star}$ D. Vigo, $\dagger$ N. Govoni, ${ }^{\star}$ and R. Gaiani ${ }^{\star}$ \\ *Dipartimento di Morfofisiologia Veterinaria e Produzioni Animali, Facoltà di Medicina Veterinaria, \\ Università di Bologna, Via Tolara di Sopra 50, 40064 Ozzano Emilia (BO), Italia \\ †Dipartimento di Scienze e Tecnologie Veterinarie per la Sicurezza Alimentare, Facoltà di Medicina Veterinaria, \\ Università di Milano, Via Celoria 10, Italia
}

\begin{abstract}
To investigate the correlation between lactation and thyroid hormone metabolism, the authors studied concentrations of total and free thyroxine (T4 and fT4), triiodothyronine (T3 and fT3), and reverse triiodothyronine (rT3) in plasma and milk, as well as liver and mammary gland 5'-deiodinase (5'D) activity in dry, early, middle, and late lactating dairy cows. Cows in early lactation show lower plasma levels of T4 and rT3 than dry, middle, and late lactating animals, whereas T3 shows the lowest plasma levels in the dry period; free T4 and T3 show a similar pattern. In early lactation there is a clear decrease in liver 5'D associated with a notable increase in mammary 5 'D. Concentrations of T4 and T3 in milk drop significantly in the first few days after delivery, whereas rT3 increases up to the fourth month. The findings suggest a relationship between the hypothyroid status of lactating cows and the rearrangement of organ-specific 5'-deiodinase activity related to the maintenance of the udder's function.
\end{abstract}

(Key words: dairy cows, mammary gland, liver, thyroid hormones)

Abbreviation key: $\mathbf{T 3}=3,5,3$ '-triiodothyronine, f'T3 $=$ free triiodothyronine, $\mathbf{T 4}=$ thyroxine, $\mathbf{f T 4}=$ free thyroxine, $\mathbf{r T 3}=$ reverse triiodothyronine, $\mathbf{5}^{\prime} \mathbf{D}=5$ '-deiodinase, D1 = type I 5'-deiodinase, D2 = type II 5'-deiodinase, $\mathbf{P T U}=$ propylthiouracil, DTT $=$ dithiothreitol.

\section{INTRODUCTION}

During early lactation, dairy cows show metabolic stress, mainly due to the excessive energy demands imposed by the lactating udder; the setting and maintenance of this homeorhetic response involve many endocrine and neuroendocrine signals (Bauman and Currie, 1980; Aceves et al., 1985). One of these endocrine factors

Received February 25, 2002.

Accepted July 8, 2002.

Corresponding author: C. Pezzi; e-mail: cpezzi@vet.unibo.it. is thyroid hormones, the importance of which during lactation in cows has long been recognized. However, early lactation in cows is further characterized by a decrease in thyrozine (T4) and 3,5,3'-triiodothyronine (T3) serum concentrations, with an inverse relationship between milk yield and circulating levels of thyroid hormones (Vanjonack and Johnson, 1975; Hart et al., 1979; Walsh et al., 1980; Blum et al., 1983; Bitman and Akers, 1984; Refsal et al., 1984; Nixon et al., 1988; Kahl et al., 1991). The physiological hypothyroid state that characterizes lactating cows is also in contrast with the enhancement in milk output induced by T3 (Slebodzinski et al., 1999). The thyroid gland principally synthesizes T4, considered a prohormone, whereas the metabolically active T3 is mainly generated in extrathyroidal tissues by enzymatic 5'-deiodination of T4 (Chopra et al., 1978).

5'-Deiodinase is a family of selenoenzymes containing selenocysteine at the active site, which catalyze the deiodination of T4, T3, and reverse triiodothyronine(rT3). Three different isotypes have been identified up to now: type I (D1), type II (D2), and type III deiodinase. D1 is able to deiodinate both the inner and outer ring of T4 and is sensitive to inhibition by propylthiouracil (PTU); it is present predominantly in the liver, kidney, and thyroid gland but is also detected in other parts of the body, such as muscle tissue, the lungs, and the pituitary gland. D2 is only an outer-ring deiodinase and is relatively insensitive to PTU; this property is useful for the purpose of distinguishing its activity from the activity of D1. D2 has been found in the central nervous system, skin, and brown adipose tissue (Köhrle, 1999). Type III deiodinase is only an inner-ring deiodinase, as it inactivates the prohormone T4 and active T3 to form, respectively, rT3 and diiodothyronine (Köhrle, 1999).

Studies on 5'-deiodinase (5'D) have also focused on mammary tissue in several species. 5'D activity was first observed in the rat, with the biochemical characteristics of D1 (Valverde and Aceves, 1989); subsequently, 5 'D was found in the mammary gland of cows, and it was primarily identified with D2 (Capuco et al., 1989; Kahl et al., 1993). In the sow's mammary tissue, 5'D seems to be a mixture of D1 and D2 (Kahl et al., 1993). 
More recently D2, but not D1, was also found in the mammary gland of mice (Song et al., 2000).

D1 and D2 activity are strongly correlated with thyroid hormone status: D1 activity decreases in hypothyroidism and increases in hyperthyroidism; conversely, D2 activity increases in hypothyroidism and decreases in hyperthyroidism (Sharifi and St Germain, 1992). D1 is generally believed to be the major contributor to the circulating plasma T3, whereas the catalysis of T4 by D2 is primarily responsible for the production of T3 within specialized tissues, producing adequate intracellular levels of T3 to ensure all T3-dependent cellular functions in the tissues. Therefore, peripheral deiodination plays a primary role in regulating thyroid homeostasis and concomitantly reflects the metabolic balance of the organism (Chopra et al., 1978; Larsen et al., 1981).

In rats it has been demonstrated that during lactation there is an opposite rearrangement of the extrathyroidal deiodinase activity. As lactation proceeds, there is a decrease in liver 5'-deiodinase (Kahl et al., 1987) and a concomitant increase in mammary gland 5'D activity (Aceves and Valverde, 1989; Valverde and Aceves, 1989; Jack et al., 1994;). This local production of T3 is important to support the high expenditure of energy that characterizes lactation. To our knowledge, no data have been published that demonstrate a similar relationship between hepatic and mammary 5'-deiodinase in cows; hence the present study was designed to measure serum and milk T4, T3, and rT3 concentrations and to determine mammary and hepatic deiodinative activity at different stages of lactation in cows.

\section{MATERIALS AND METHODS}

\section{Reagents}

Nonradioactive iodothyronines, Dowex 50W-X2, PTU and dithiothreitol (DTT) were purchased from Sigma Chemical Co. (St. Louis, MO). [ $\left.{ }^{125} \mathrm{I}\right] \mathrm{T} 4(1320 \mu \mathrm{Ci} / \mu \mathrm{g})$ and $\left[{ }^{125} \mathrm{I}\right] \mathrm{rT} 3(1250 \mu \mathrm{Ci} / \mu \mathrm{g})$ were obtained from Perkins Elmer LifeSciences (Boston, MA). Sep-Pak cartridges (C18) were obtained from Waters. Radioimmunoassay kits for hormonal dosages in biological fluids were purchased from DPC (Los Angeles, CA) for total and free T4 and T3 and from Biodata (Rome, Italy) for rT3. All other reagents were of the highest purity commercially available.

\section{Animals and Experimental Design}

To measure the concentration of thyroid hormones in serum and milk, we used 15 high-yielding ItalianFriesian cows. Animals were housed in individual stalls in a clean and temperature-controlled environment and had free access to food and water. On every collecting day, three blood samples were taken at 1-h intervals. The days of collection were at delivery (d 0$), d 5$, and 15 of lactation, and then monthly until the ninth month of lactation; one sample was also taken in the dry period. Plasma from each animal was divided in aliquots and frozen at $-20^{\circ} \mathrm{C}$ until assayed.

At delivery (d 0) and until the fourth month of lactation, on the same days that blood was collected, samples of whole milk were taken at the early morning milking (the samples of d 0 were considered colostrum). We recorded daily milk production once a month throughout the experimental period. To measure changes in 5'deiodinase activity during lactation, liver and mammary gland samples were obtained at slaughter from six bovines for each group: early ( 1 to $3 \mathrm{mo}$ ), mid (4 to $6 \mathrm{mo}$ ), and late $(\geq 7 \mathrm{mo})$ stages of lactation and dry period (cows were chosen not pregnant, 1 mo after the beginning of dry period). Tissues were immediately frozen in liquid nitrogen and stored at $-80^{\circ} \mathrm{C}$ until analysis.

\section{Radioimmunoassay}

All samples (plasma, colostrum, and milk) were analyzed in duplicate by radioimmunoassay for total and free T4, T3, and for rT3 evaluation. Parallelism with standard curves and scalar dilution of bovine plasma and milk were tested and for all assays showed no difference $(\mathrm{P}<0.01)$. Colostrum and milk samples were defatted by centrifugation before radioimmunoassay, even though in preliminary tests we did not find any differences in the distribution of labeled thyroid hormones in milk fractions. In other experiments we added bovine gamma-globulins (as in colostrum) or commercial milk to standard curves in order to exclude interference in radioimmunoassay.

Validation parameters of the method were assay sensitivity $0.13 \mathrm{ng} / \mathrm{ml}$ for T3, $0.41 \mathrm{pg} / \mathrm{ml}$ for fT3, $6.96 \mathrm{ng} /$ $\mathrm{ml}$ for T4, $0.17 \mathrm{pg} / \mathrm{ml}$ for free thyrozine (fT4), and 0.027 $\mathrm{ng} / \mathrm{ml}$ for rT3; intra- and interassay coefficients of variation (\%) were 7.08 and 11.10 for T3, 8.21 and 10.45 for fT3, 6.44 and 10.72 for T4, 10.12 and 14.03 for fT4, and 6.48 and 7.60 for rT3.

\section{5'-Deiodinase Activity}

Tissue samples were assayed for 5'-deiodinase using a modification of published methods (Leonard and Rosenberg, 1980; Salvatore et al., 1996). In brief, tissues were homogenized in ice-cold $0.25 \mathrm{M}$ sucrose, $50 \mathrm{mM}$ Tris- $\mathrm{HCl}(\mathrm{pH} 7.5)$ and $1 \mathrm{~m} M$ EDTA. Homogenates were centrifuged at $20,000 \times \mathrm{g}$ for $20 \mathrm{~min}$ at $4^{\circ} \mathrm{C}$. The 20,000 $\times \mathrm{g}$ supernatants were centrifuged at $20,000 \times \mathrm{g}$ for 90 
min at $4^{\circ} \mathrm{C}$ to separate the supernatant fraction from the microsomal fraction. The pellets were suspended in the homogenization buffer and stored at $-80^{\circ} \mathrm{C}$ until analysis.

Deiodinase activity was assayed by incubating 300 $\mu \mathrm{g}$ of microsomal protein, $3 \mathrm{~h}$ for mammary tissues and $1 \mathrm{~h}$ for hepatic tissue, at $37^{\circ} \mathrm{C}$. The incubation mixture contained 150,000 cpm $\left[{ }^{125} \mathrm{I}\right] \mathrm{T} 4$ (D2 activity) or $\left[{ }^{125} \mathrm{I}\right] \mathrm{rT} 3$ (D1 activity) purified on Sep-Pak cartridges, and nonradioactive thyronine ( $2 \mathrm{n} M$ of T4 or rT3), as well as DTT (25 and $5 \mathrm{mM}$, respectively) and PTU (only in the D2 assay, $1 \mathrm{~m} M$ ) in a final volume of $300 \mu \mathrm{l}$. The reaction was terminated by adding $50 \mu \mathrm{l}$ of an ice-cold solution containing $50 \%$ normal bovine serum and $10 \mathrm{~m} M$ PTU and $350 \mu \mathrm{l}$ of $10 \% \mathrm{TCA}$. The acid-soluble radioiodide was isolated by chromatography on Dowex 50W-X2 columns eluted twice with $3 \mathrm{ml}$ of 10\% acetic acid. Parallel control tubes without homogenates were incubated in each assay. The radioactivity was measured, and net radioactivity was determined by subtracting the value obtained with controls from that of enzyme samples. Results are expressed as fmol I released/mg protein/h for mammary tissue and as nmol I released/mg protein/ $\mathrm{h}$ for liver tissue. Protein concentration was measured with the protein assay kit (BioRad) using BSA as standard.

\section{Statistical Analysis}

The significance of differences between thyroid hormone concentration and liver and mammary gland 5'deiodinase activity in different periods of lactation was determined by ANOVA. Data are expressed as means \pm standard deviation $(\mathrm{X} \pm \mathrm{SD})$. Correlation coefficients were obtained using linear regression models. Differences with $\mathrm{P}<0.05$ were considered statistically significant.

\section{RESULTS}

In Figure 1 we show the mean values $(\mathrm{X} \pm \mathrm{SD})$ of total and free T3 and T4 and rT3 plasma levels grouped in four stages of lactation: early ( 1 to $3 \mathrm{mo}$ ), middle (4 to $6 \mathrm{mo}$ ), late ( $\geq 7 \mathrm{mo})$, and dry period. Total and free thyroid hormones exhibit nearly identical profiles in response to the stage of lactation for both T4 and T3. Total and free T4 plasma concentrations showed the lowest value in the early stage of lactation $(31.6 \pm 1.4$ $\mathrm{ng} / \mathrm{ml}$ and $3 \pm 0.3 \mathrm{pg} / \mathrm{ml}$, respectively). Plasma concentrations increased in mid- and late lactation and peaked in the dry period $(43.11 \pm 1.23 \mathrm{ng} / \mathrm{ml}$ and $5.17 \pm 0.36$ $\mathrm{pg} / \mathrm{ml}$, respectively), and a significant difference was observed among the stages of lactation $(\mathrm{P}<0.01)$, except in the case of total T4, which showed no difference

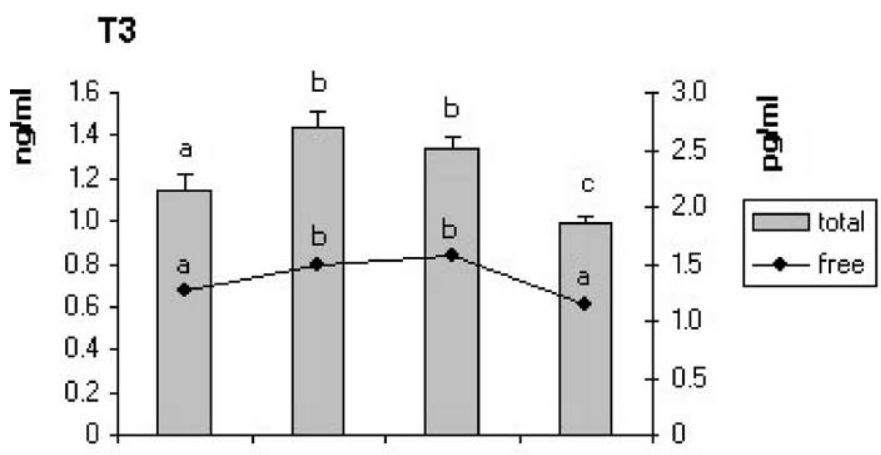

\section{T4}

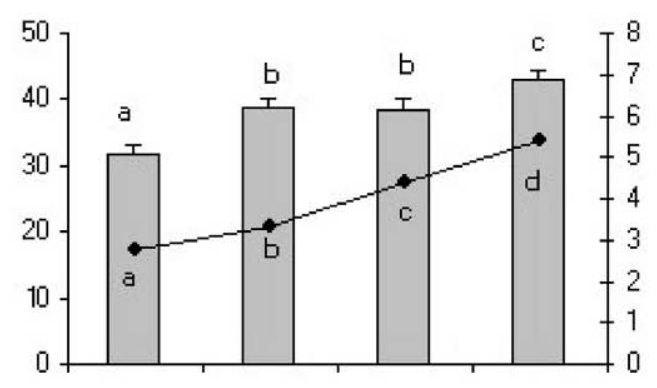

rT3

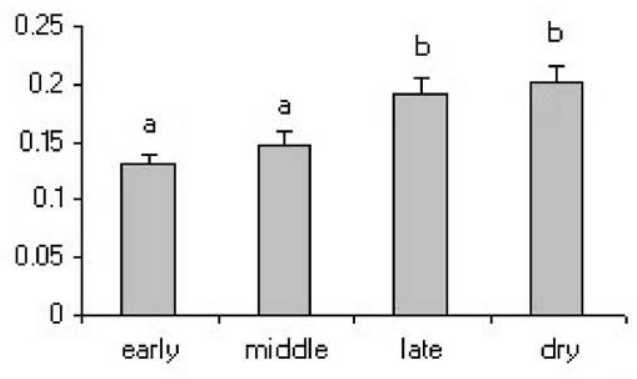

stage of lactation

Figure 1. Effect of the stage of lactation-early (1 to 3 mo), middle ( 4 to $6 \mathrm{mo}$ ), late $(\geq 7 \mathrm{mo}$ ), and dry period-on plasma total and free T3 and T4 and rT3 concentration in Italian-Friesian cows. Values are means $\pm \mathrm{SD}$; different letters represent significant differences $(P$ $<0.01)$.

between mid- and late stages. Furthermore, there was a significant correlation $(\mathrm{P}<0.01)$ with total $\mathrm{T} 4$ and milk production $(\mathrm{r}=-0.68)$ in the early, middle, and late lactation periods.

Total T3 was low in early lactation $(1.15 \pm 0.07 \mathrm{ng} /$ $\mathrm{ml})$; then its concentration increased in midlactation $(\mathrm{P}$ $<0.01)$. In the dry period, the T3 concentrations in plasma decreased to the lowest value $(0.99 \pm 0.04 \mathrm{ng} /$ $\mathrm{ml}$ ) compared with the concentrations in lactating periods $(\mathrm{P}<0.01)$. With regard to rT3 concentrations, we saw lower concentrations in early and midlactation $(0.13 \pm 0.03$ and $0.15 \pm 0.03 \mathrm{ng} / \mathrm{ml}$, respectively) com- 
Table 1. Mean values \pm SD of thyroid hormone concentration in colostrum (0) and milk of Italian-Friesian cows in the first 4 mo of lactation (values in the same column bearing different letters differ significantly, $\mathrm{P}<0.01)$

\begin{tabular}{llllll}
\hline \multirow{2}{*}{ Days of lactation } & $\begin{array}{l}\mathrm{T} 3 \\
\mathrm{ng} / \mathrm{ml}\end{array}$ & $\begin{array}{l}\mathrm{fT3} \\
\mathrm{pg} / \mathrm{ml}\end{array}$ & $\begin{array}{l}\mathrm{T} 4 \\
\mathrm{ng} / \mathrm{ml}\end{array}$ & $\begin{array}{l}\mathrm{fT} 4 \\
\mathrm{pg} / \mathrm{ml}\end{array}$ & $\begin{array}{l}\mathrm{rT3} \\
\mathrm{ng} / \mathrm{ml}\end{array}$ \\
\hline 0 & $2.02 \pm 0.29 \mathrm{a}$ & $3.54 \pm 0.81 \mathrm{a}$ & $1.9 \pm 0.96 \mathrm{a}$ & $0.70 \pm 0.1 \mathrm{a}$ & $0.57 \pm 0.06 \mathrm{a}$ \\
5 & $1.09 \pm 0.15 \mathrm{~b}$ & $1.35 \pm 0.28 \mathrm{~b}$ & $0.3 \pm 0.1 \mathrm{~b}$ & $0.20 \pm 0.1 \mathrm{~b}$ & $0.75 \pm 0.07 \mathrm{~b}$ \\
15 & $0.94 \pm 0.13 \mathrm{~b}$ & $0.80 \pm 0.23 \mathrm{bc}$ & $0^{*}$ & $0^{*}$ & $1.14 \pm 0.37 \mathrm{bc}$ \\
30 & $0.45 \pm 0.18 \mathrm{c}$ & $0.49 \pm 0.21 \mathrm{c}$ & $0^{*}$ & $0^{*}$ & $1.37 \pm 0.24 \mathrm{c}$ \\
60 & $0.28 \pm 0.10 \mathrm{c}$ & $0.33 \pm 0.14 \mathrm{c}$ & $0^{*}$ & $0^{*}$ & $2.03 \pm 0.22 \mathrm{~d}$ \\
90 & $0.33 \pm 0.14 \mathrm{c}$ & $0.13 \pm 0.06 \mathrm{~d}$ & $0^{*}$ & $0^{*}$ & $1.58 \pm 0.46 \mathrm{abcd}$ \\
120 & $0.41 \pm 0.10 \mathrm{c}$ & $0.43 \pm 0.14 \mathrm{c}$ & $0^{*}$ & $0^{*}$ & $3.48 \pm 0.44 \mathrm{e}$ \\
\hline
\end{tabular}

*Values under the method's detection sensitivity.

pared with the concentrations in late lactation and in the dry period $(0.19 \pm 0.05 \mathrm{ng} / \mathrm{ml}$ and $0.20 \pm 0.05 \mathrm{ng} / \mathrm{ml}$, respectively), with significant changes between early to midlactation and late to dry stages $(\mathrm{P}<0.01)$. Mean values $(\mathrm{X} \pm \mathrm{SD})$ for total and free $\mathrm{T} 3$ and $\mathrm{T} 4$ and $\mathrm{rT} 3$ concentrations in milk in the early stage of lactation are presented in Table 1.

T3 milk concentrations showed a downward trend as lactation advanced: it was high in colostrum (day 0: $2.02 \pm 0.29 \mathrm{ng} / \mathrm{ml}$ ), had halved by $\mathrm{d} 5$ and continually decreased during the first month $(\mathrm{P}<0.05)$. From the end of the first month to the end of the experimental period, T3 milk concentrations did not show any statistical variation. The same pattern was observed in fT3. Total and free T4 were present in a very low concentration in colostrum, and in the subsequent samples the value was below the method's detection limit. Low concentrations of rT3 were detected in colostrum $(0.57 \pm$ $0.06 \mathrm{ng} / \mathrm{ml}$ ), but the levels increased until the end of the experimental period.

Figure 2 shows 5'-deiodinase activity in the mammary gland and liver of Italian-Friesian cows during different stages of lactation. Results are expressed as the mean \pm SD of six cows per experimental group. Liver D1 activity was significantly lower in early lactation than in other periods. As lactation proceeded, 5'D in liver increased, reaching the highest activity in late lactation and during the dry period ( $555.16 \pm 10.08$ and $725.85 \pm 23.60 \mathrm{nmol} / \mathrm{mg}$ proteins per $\mathrm{h}$, respectively). On the contrary, mammary gland D2 activity showed a downward pattern from the highest value in early lactation $(46.54 \pm 1.99 \mathrm{fmol} / \mathrm{mg}$ proteins per $\mathrm{h})$ to the dry period $(\mathrm{P}<0.0001)$. A significant $(\mathrm{P}<0.001)$ negative correlation exists between 5'-diodinase activity in the liver and mammary gland $(\mathrm{r}=-0.86)$; moreover, as depicted in Figure 3, daily milk yield exhibited a significant correlation $(\mathrm{P}<0.001)$ with liver and mammary gland enzymatic activity ( $\mathrm{r}=-0.77$ and 0.83 , respectively).

\section{DISCUSSION}

To our knowledge, the results of this study provide the first evidence of a negative correlation between hepatic and mammary 5'-deiodinase activity in cows. In

\section{mammary gland}

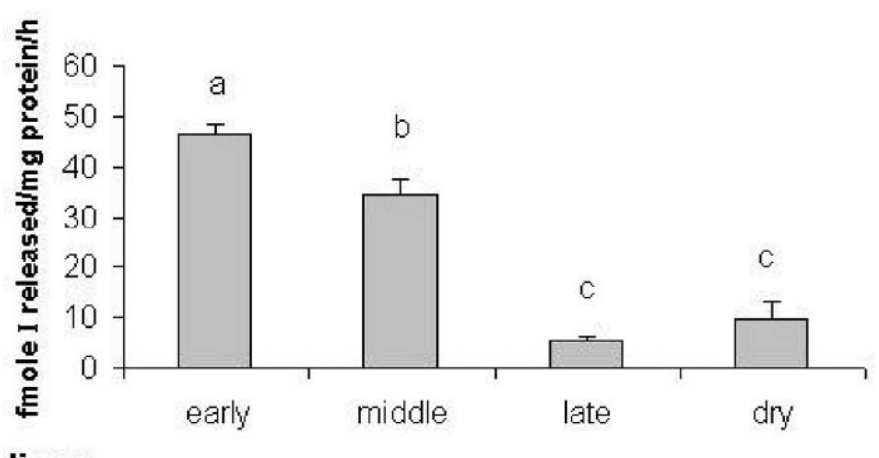

\section{liver}

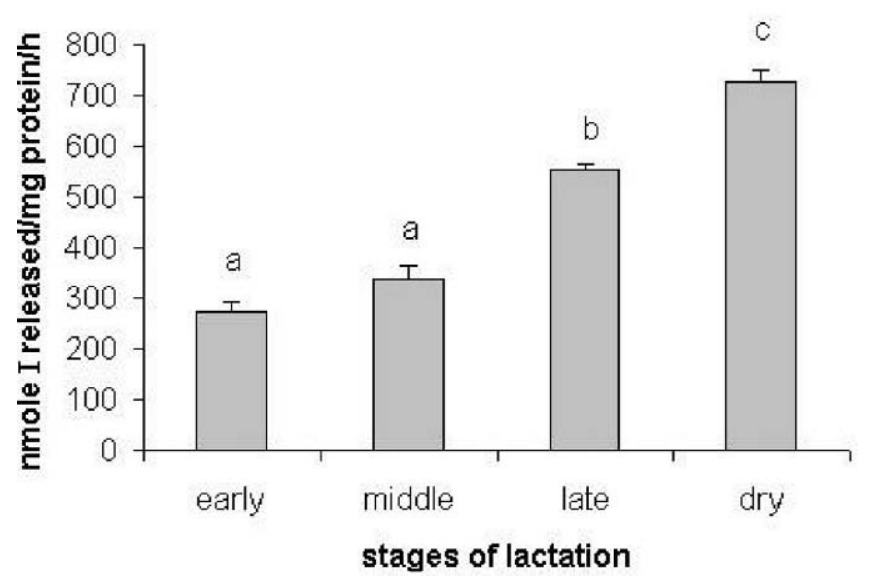

Figure 2. Type II 5'-deiodinase activity in mammary tissue (upper panel) and Type I 5'-deiodinase activity in the liver (lower panel) of Italian-Friesian cows at different stages of lactation: early (1 to 3 $\mathrm{mo}$ ), middle (4 to $6 \mathrm{mo}$ ), late ( $\geq 7 \mathrm{mo}$ ) and dry period. Values are means \pm SD; bars bearing different letters differ significantly $(P<0.05)$. 


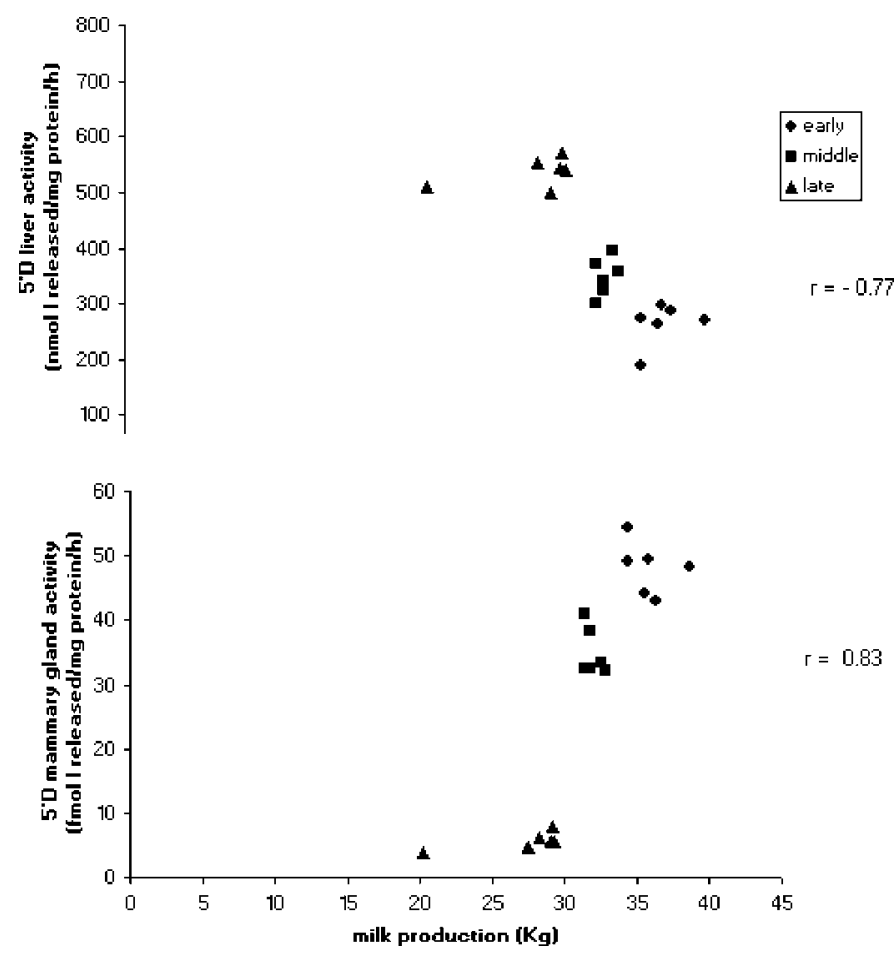

Figure 3. Relationship between milk production and 5'-deiodinase activity in the liver and mammary gland of Italian-Friesian cows in different stage of lactation (early, middle, and late lactation, and dry period). Milk production shows a direct correlation with mammary enzyme activity (Type II isoenzyme) and an indirect correlation with liver enzyme activity (Type I isoenzyme); both correlations are significant $(P<0.001)$.

the literature there are many reports on peripheral deiodination in lactating rodents, and a correlation between peripheral 5'D activity, circulating thyroid hormones, and intensity of lactation has already been established (Aceves and Valverde, 1989; Valverde and Aceves, 1989; Kahl et al., 1997). In rats, peripheral thyronine metabolism shows an opposite rearrangement of the extrathyroidal deiodinase activity, which is probably associated with organ-specific demands. In fact, a significant rise in mammary 5'-deiodinase activity appears only during the functional period of the gland when the liver has the lowest 5'D activity (Valverde and Aceves, 1989).

This article also demonstrates that in dairy cows there is an opposite reorganization in liver and mammary gland 5'-deiodinase activity. Bovine mammary gland type II 5'-deiodinase activity during early lactation, when the mammary gland produces high quantities of milk, was significantly higher than in the dry period, and there was a significant correlation between milk yield and mammary gland 5'D. An opposite trend was demonstrated in liver type I 5'D activity; the lowest value was detected in early lactating cows, and then, as lactation proceeded, it increased to reach a peak in the dry period. The same pattern has been observed in rodents, which demonstrate a clear decrease in liver 5 'D at the peak of lactation (Valverde and Aceves, 1989).

The opposite course shown by mammary and liver 5 '-deiodinase activity in lactating animals could depend on the different regulation of the two isoenzymes, due either to the plasma concentrations of thyroid hormones or to the presence of liver steatosis, which is characteristic of cows in this phase of lactation. As a consequence of steatosis, fatty acids accumulate in the liver parenchyma, and it has been demonstrated that some fatty acids inhibit type-I liver 5'-deiodinase activity (Romo et al., 1997).

The increased exploitation of thyroid hormones by the lactating mammary gland or the altered 5'D activity in liver (the main plasma-T3-producing tissue) could be among the causes of the functional hypothyroid state in early lactating animals. In fact, the hypothyroid state enhances mammary D2 activity and inhibits liver D1 activity. T4 produced by the thyroid gland is normally transformed into T3 by 5'-deiodination in the liver, but the deiodinating system is also present in other peripheral tissues that produce T3 for local needs. Therefore, the mammary gland's T3 production could be an important factor for milk production, considering the fact that early lactation in dairy cows is characterized by a negative energy balance and that the thyroid hormone has a known role in maintaining energy expenditure for high-priority functions (Bauman and Currie, 1980).

Results from the current study have shown that plasma T4, T3, and rT3 concentrations were low in early lactation and then continued to rise until the end of lactation, with a significant negative correlation with milk production. In the dry period we found high concentrations of T4 and rT3 and low levels of T3. It is very difficult to compare our findings with those of other authors given that there is a great disagreement among data and experimental procedures. In agreement with Tiirats (1997), the present study shows low T3 concentrations in early lactation and in the dry period, low T4 and rT3 concentrations in early lactation, and high concentrations in cows during the dry period. It should be pointed out that the rT3 serum concentration pattern is not clear, since some authors (Akasha et al., 1987) have found no difference during lactation, whereas other studies (Aceves et al., 1985) reported a high value in early lactation and a decrease in the other stages, that is, opposite results from our own.

In dry-period animals, the thyroid hormone's pattern, characterized by high T4 and rT3 and low T3, could be due to an increase in thyroid secretion, which is in turn induced by the high energy consumption typical of pregnancy (Tiirats, 1997) and fetal development 
(Strbak and Tomsik, 1988). Furthermore, an activation of the deiodinating system degrading $\mathrm{T} 4$ and $\mathrm{T} 3$ to rT3 may take place to balance for elevated thyroid secretion.

In conclusion, we can affirm that in early lactation, dairy cows are in a hypothyroid state, but the question remains open as to whether the hypothyroid state in lactating animals is the cause or the consequence of diminished liver 5'D activity. One of the possible explanations of this hypothyroid state of lactating cows is the secretion of thyroid hormones into milk. Certainly thyroid hormones are present in milk, as confirmed by other authors (Magdub et al., 1979; Thompson-Ball and Anderson, 1980; Akasha and Anderson, 1984; Akasha et al., 1987); however, the concentrations are low. In this study we found that thyroid hormone concentrations in milk exhibited variations opposite of plasma concentrations. In fact, the highest T3 and T4 concentrations were in colostrum (sample 0), when the thyroid hormone plasma levels were the lowest. On d 15, T4 milk concentrations were undetectable, and T3 was similar to plasma concentrations; then the T3 value at 1 mo remained stable until the end of the experimental period.

Judging from the low concentrations of T3 and the lack of T4 in milk even after 1 mo of lactation, the thyroid hormone's pattern in blood at the beginning of lactation cannot be due only to transport of the thyroid hormone from plasma through the mammary gland.

The rT3 showed a trend opposite to T3 and T4 in milk. It was present at low levels at delivery, and subsequently, its concentration increased up to the end of the experimental period, showing a pattern similar to the plasma concentrations. A possible explanation of this rT3 milk-concentration pattern is the presence of a deiodinase enzyme in cow's milk, which converts thyroid hormones coming from the blood or from intramammary production to form the inactive thyronine metabolite rT3 (Slebodzinski et al., 1998).

The evidence provided by this experiment suggests an important role of 5'-deiodinase in regulating the needs and functions of lactating mammary glands in cows. However, some further studies are necessary to clarify the role of the main galactopoietic hormones in controlling 5'-deiodinase during lactation.

\section{ACKNOWLEDGMENTS}

This work was supported by M.U.R.S.T. (Ministero dell'Istruzione dell'Università e della Ricerca).

\section{REFERENCES}

Aceves, C., A. Ruiz-J, C. Romero, and C. Valverde-R. 1985. Homeorhesis during early lactation. Euthyroid sick-like syndrome in lactating cows. Acta Endocrinol. 110:505-509.
Aceves, C., and C. Valverde. 1989. Type I, 5'-monodeiodinase activity in the lactating mammary gland. Endocrinol. 124:2818-2820.

Akasha, M. A., and R. R. Anderson. 1984. Thyroxine and triiodothyronine in milk of cows, goats, sheep and guinea pig. Proc. Soc. Exp. Biol. Med. 177:360-371.

Akasha, M. A., R. R. Anderson, M. Ellersieck, and D. A. Nixon. 1987. Concentration of thyroid hormones and prolactin in dairy cattle serum and milk at three stages of lactation. J. Dairy Sci. 70:271-276.

Bauman, D. E., and W. B. Currie. 1980. Partitioning of nutrients during pregnancy and lactation: A review of mechanisms involving homeostasis and homeorhesis. J. Dairy Sci. 63:1514-1529.

Bitman, J. H., and R. M. Akers. 1984. Triiodothyronine and thyroxine during gestation in dairy cattle selected for high and low milk production. J. Dairy Sci. 67:2614-2619.

Blum, J. W., P. Kunz, and H. Leuenberger. 1983. Thyroid hormones, blood plasma metabolites and hepatological parameters in relationship to milk yield in dairy cows. Anim. Prod. 36:93.

Capuco, A. V., J. E. Keys, and J. J. Smith. 1989. Somatotrophin increases thyroxine-5'-monodeiodinase activity in lactating mammary tissue of the cow. J. Endocrinol. 121:205-211.

Chopra, I. J., D. H. Solomon, U. Chopra, S. Yung Wu, D. A. Fisher, and Y. Nakamura. 1978. Pathways of metabolism of thyroid hormones. Recent Prog. Horm. Res. 34:521-532.

Hart, I. C., J. A. Bines, and S. V. Morant. 1979. Endocrine control of energy metabolism in the cow for stages of lactation. J. Dairy Sci. 62:270-277.

Jack, L. J. V., S. Khal, D. L. St Germain, and A. V. Capuco. 1994. Tissue distribution and regulation of 5'-deiodinase processes in lactating rats. J. Endocrinol. 142:205-215.

Kahl, S., J. Bitman, A. V. Capuco, and J. E. Keys. 1991. Effect of lactational intensity on extrathyroidal 5'-deiodinase activity in rats. J. Dairy Sci. 74:811-818.

Kahl, S., A. V. Capuco, and J. Bitman. 1987. Serum concentrations of thyroid hormones and extrathyroidal thyroxine-5'-monodeiodinase activity during lactation in the rat. Proc. Soc. Exp. Biol. Med. 184:144-150.

Kahl, S., L. J. W. Jack, and A. V. Capuco. 1993. Characterization of thyroxine-5'-deiodinase in mammary tissue of the cow, sow and rat. Livest. Prod. Sci. 35:177-178.

Köhrle, J. 1999. Local activation and inactivation of thyroid hormones: The deiodinase family. Mol. Cell. Endocrinol. 151:103119.

Larsen, P. R., J. E. Silva, and M. M. Kaplan. 1981. Relationship between circulating and intracellular thyroid hormones: Physiological and clinical implications. Endocrinol. Rev. 2:87-102.

Leonard, J. L., and I. N. Rosenberg. 1980. Iodothyronine 5'-deiodinase from rat kidney: Substrate specificity and the 5'-deiodination of reverse triiodothyronine. Endocrinol. 107:1376-1383.

Magdub, A. B., F. D. El-Nouty, and H. D. Johnson. 1979. Effect of milking and milking level on thyroxine in plasma and milk. J. Dairy Sci. 62(Suppl. 1):114(Abstr.).

Nixon, D. A., M. A. Akasha, and R. R. Anderson. 1988. Free and total thyroid hormones in serum of Holstein cows. J. Dairy Sci. 71:1152-1160.

Refsal, K. R., R. F. Nachreiner, and C. R. Anderson. 1984. Relationship of season, herd, lactation, age, and pregnancy with serum thyroxine and triiodothyronine in Holstein cows. Domest. Anim. Endocrinol. 1:225.

Romo, G. A., T. H. Elsasser, S. Khal, R. A. Erdman, and D. P. Casper. 1997. Dietary fatty acids modulate hormone responses in lactating cows: Mechanistic role for 5'-deiodinase activity in tissue. Domest. Anim. Endocrinol. 14:409-420.

Salvatore, D., H. Tu, J. W. Harney, and P. P. Larsen. 1996. Type 2 iodothyronine deiodinase is highly expressed in human thyroid. J. Clin. Invest. 98:962-968.

Sharifi, J., and D. L. St Germain. 1992. The cDNA for the type I iodothyronine 5'-deiodinase encodes an enzyme manifesting both high $\mathrm{km}$ and low $\mathrm{km}$ activity. Evidence that rat liver and kidney contain a single enzyme which converts thyroxine to $3,5,3$ '-triiodothyronine. J. Biol. Chem. 267:12539-12544. 
Slebodzinski, A. B., E. Brzezinska-Slebodzinska, J. Nowak, and K. Kowalska. 1998. Triiodothyronine (T3), insulin and characteristics of 5'-monodeiodinase (5'-MD) in mare's milk from parturition to 21 days post-partum. Reprod. Nutr. Dev. 38:235-244.

Slebodzinski, A. B., E. Brzezinska-Slebodzinska, E. Styczynska, and M. Szejnoga. 1999. Presence of thyroxine deiodinase in mammary gland: Possible modulation of the enzyme-deiodinating activity by somatotropin. Domest. Anim. Endocrinol. 17:161-169.

Song, S., K. Sorimachi, K. Adachi, and T. Oka. 2000. Biochemical and molecular biological evidence for the presence of type II iodothyronine deiodinase in mouse mammary gland. Mol. Cell. Endocrinol. 160:173-181.

Strbak, V., and F. Tomsik. 1988. Thyroid levels in cow maternal and fetal sera during last trimester of pregnancy. Endocrinol. Exp. 22:113-116.
Thompson-Ball, T., and R. R. Anderson. 1980. Thyroid hormone concentrations in blood and milk of dairy cows. J. Dairy Sci. 63(Suppl. 1): 82(Abstr.)

Tiirats, T. 1997. Thyroxine, triiodothyronine and reverse-triiodothyronine concentrations in blood plasma in relation to lactational stage, milk yield, energy and dietary protein intake in Estonian dairy cows. Acta Vet. Scand. 38:339-348.

Valverde, C., and C. Aceves. 1989. Circulating thyronines and peripheral monodeiodination in lactating rats. Endocrinol. 124:1340 1344.

Vanjonack, W. J., and H. D. Johnson. 1975. Effect of moderate heat and milk yield on plasma thyroxine in cattle. J. Dairy Sci. 58:507-511.

Walsh, D. S., J. J. Vasely, and S. Mahadevan. 1980. Relationship between milk production and circulating hormones in dairy cows. J. Dairy Sci. 63:290-294. 